\title{
Investor Sentiment by Money Flow Index and Stock Return
}

\author{
Lai Cao Mai Phuong ${ }^{1}$ \\ ${ }^{1}$ Industrial University of Ho Chi Minh City, Viet Nam \\ Correspondence: Lai Cao Mai Phuong, Industrial University of Ho Chi Minh City, Viet Nam.
}

Received: January 1, 2021

Accepted: February 17, 2021

Online Published: March 18, 2021

doi:10.5430/ijfr.v12n4p33

URL: https://doi.org/10.5430/ijfr.v12n4p33

\begin{abstract}
Factors affecting stock prices have been studied by many scholars on different stock markets. However, the number of empirical studies applying technical analysis indicators to measure investor sentiment is quite limited. To explore this interesting topic, this study uses the Money Flow Index (MFI) indicator to measure an investor's sentiment by various thresholds and to test its effect on the excess return on Vietnam stock market. Data series including market, interest rate, finance and transaction data of 138 companies listed on the Ho Chi Minh City Stock Exchange from 2015 to June 2020 are used in the equations Regression. The study's findings show that, after controlling for market factors, individual characteristics and liquidity of each company, investor sentiment as measured by the MFI indicator still has a significant impact on the return of stocks at all thresholds. In addition, when the MFI value area is near the starting and ending point of the scale (less than 20, greater than 80), the regression coefficients of these two thresholds and control variables both increase compared to the remaining models, return and significant effect to the excess return of the securities.
\end{abstract}

Keywords: money flow index, sentiment, psychological factors, excess return, CAMP

\section{Introduction}

The literature review has been drawn based on old references and need to be updated with recent reference and critically discuss the existing knowledge.

The normativefinancial theory holds that the majority of investors in the market are reasonable investors. If there are unreasonable investors in the market, their actions are weak and in the minority, so they are not likely to become market trends. Because efficiency theory believes that there is always a mechanism to correct the market of efficiency states. However, the reality is that the financial market bubbles occurred like the stock bubble in the United States during 1920 to mid 1929, the Dotcom technology bubble on the Nasdaq exchange in the late 1990s, normative financial theory cannot provide a convincing explanation.

Behavioral theory recognizes the role of unreasonable investors in the market, so when these irrational actions take place continuously and become market trends, price bubbles will be created. The application of behavioral finance not only explains the irrational behavior of investors, but goes further, it also adjusts the pricing patterns of financial assets.

William Sharpe has developed a Single Index Model that describes the relationship between the return of a particular security and the return of the entire market, and measures the systemic risk of individual securities. While the single index model is a regression model that uses historical data, it provides a solid scientific basis for the relationship between the return of an individual security and that of the market, the The CAPM figure also developed by William Sharpe is used to estimate the expected rate of return for securities (Sharpe, 1964).

In fact, there have been many studies exploring the financial factors that affect the expected return of securities by extending the CAPM model. However, research on measuring investor sentiment with technical analysis indicators is still very limited. In order to exploit this research gap, this article will measure investor sentiment by MFI indicator to study its impact on excess return on Vietnam's stock market.

After controlling for market factors, specific characteristics and liquidity of 138 companies listed on the Ho Chi Minh City Stock Exchange from 2015 to June 2020, the study discovered the sentiment of Investors as measured by the MFI indicator still have a significant impact on the returns of stocks at all thresholds. Especially, when the MFI value area is below 20 and above 80, its impact is even stronger. The research results have reaffirmed the importance 
of investor sentiment factors affecting the stock market, especially markets that are not yet emerging stock markets like Vietnam. In addition, this research also contributes to the academic treasure of the application of technical analysis to measure the sentiment of stock investors.

\section{Investor Sentiment, the Capital Asset Pricing Model and Factors Affecting the Excess Return of the Security}

\subsection{Investor Sentiment}

There are many ways to determine investor sentiment in the stock market (Kim \& Ha, 2010). In which the indirect way is often used based on economic theory combined with transaction data and non-financial factors to measure investor sentiment. Investor sentiment is measured by non-financial factors such as the moon's cycle (Yuan, Zheng \& Zhu, 2006; Phuong, 2012), the sun's geomagnetic field (Phuong, 2017), weather (Hirshleifer \& Shumway, 2003; Phuong, 2019). Some studies rely on trading data and technical analysis indicators to measure the impact of an investor's sentiment on excess return of securities. Recently, Phuong (2020a, 2020b) has used the Psychological Line Index and Relative Strength Index to measure investor sentiment in the stock market. The aim is to continue to expand the exploitation of technical analysis indicators on the stock market, this article measures investor sentiment by using the Money Flow Index (MFI) and its impact on profitability. interest rate on the Vietnamese stock market. Next, there will be a brief introduction to the Capital Asset Pricing Model and review of factors affecting return stock.

\subsection{The Capital Asset Pricing Model}

The Capital Asset Pricing Model (CAPM) states that the expected return of a security is equal to the risk-free return plus a risk premium based on the security's systemic risk basis. In the CAPM, the relationship between return and risk is described by the following formula:

$$
\mathrm{ERi}=\mathrm{Rf}+\beta \mathrm{i}(\mathrm{ERm}-\mathrm{Rf})
$$

where:

$$
\begin{aligned}
& \mathrm{ERi}=\text { expected return of investment } \\
& \mathrm{Rf}=\text { risk-free rate } \\
& \mathrm{Bi}=\text { beta of the investment } \\
& (\mathrm{ERm}-\mathrm{Rf})=\text { market risk premium }
\end{aligned}
$$

Many researchers have used CAPM by William Sharpe (1964) and John Lintner (1965) to measure the relationship between risk and rate of return. Because they believe this is a simple model and has strong theoretical basis.

\subsection{Factors Affecting the Excess Return of the Security}

The models that study the factors that influence stock returns are often based on CAPMs and add other factors such as -financial, liquidity - as control variables in the research models. Davis, Fama \& French (2000) research on the US stock market showed that the market premium, price -to-book value, and firm size are the factors affecting stock return. Items on financial statements such as book value, total assets, debt and earning are accounting structures rather than market variables but they still hold important information about the condition of market. Because book equity and book leverage determine how credit is given to the economy, including the financial system.

Price-to-book value is the market value divided by the book value of a share, or the $\mathrm{P} / \mathrm{B}$ can also be calculated by the company's capitalization divided by its equity.

$\mathrm{P} / \mathrm{B}$ is to compare the share's price with its book value. It shows how many times the share price is higher than the book value of the business. Firms with a high P / B are often classified as growth stocks, firms with low P / B are often classified as value stocks (Capaul, Rowley \& Sharpe, 1993). For example: P/B of share A is 3, in order to own share A, investors accept to pay 3 times the book value (equity) of that stock. A firm with a high P / B indicates that the market is looking forward to its future business prospects (Kay, 1976; Brief \& Lawson, 1992) is doing very well. Therefore, investors are willing to pay more for the book value of a company. There are scholars, on the contrary, point out that P/B reflects firm's risk. Research on US stock markets (Stattman, 1980) and India (Mohanty, 2002) shows that $\mathrm{P} / \mathrm{B}$ ratio and stock return are negatively correlated.

Experimental evidence suggests that the effect of $\mathrm{P} / \mathrm{B}$ on stock returns may vary between studies. However, it is thought that because book value is usually more stable than EPS, P/B will be better than P/E when EPS is too volatile. 
Price to earnings per share $(P / E)$ is an important indicator to price stocks. PER is calculated by the market price divided by earnings per share (EPS), or by company capitalization divided by profit after tax. It shows the price that the investor is willing to pay for a dollar profit of the stock. There are two perspectives on the P/E ratio that affects stock returns. Given that P/E is a measure of risk, one would expect that there is an inverse relationship between P/E and stock returns (Ball, 1978). On the contrary, the view that P/E represents the rate of earnings growth is expected to be positive between P/E and equity returns (Litzenberger \& Rao, 1971; Cragg \& Malkiel,1982). Companies with high $\mathrm{P} / \mathrm{E}$ are a sign that investors expect higher earnings growth in the future. Conversely, a low P / E may represent a company that is undervalued or performing better than companies have done in recent years. Professional investors often pay "premium" to leading companies, so these companies have higher P / E ratios than other stocks in the same industry.

Liquidity: expressed as the cost of converting from stock to cash and vice versa (Easley \& O'hara, 1987). Liquidity shows the flexibility and safety of investment capital, the more dynamic and effective the operating market is, the higher the liquidity of securities transactions. Amihud \& Mendelson (1986) argued that there is a correlation between stock returns and liquidity. When low liquidity is a predictor of a trend reversal in stock falsification (Pástor \& Stambaugh, 2003) and the higher the liquidity premium, the higher the return on the stock. Experimental studies on the relationship between liquidity and stock returns are inconsistent. Chan \& Faff, (2005) point out a positive relationship between liquidity and stock returns on Australian stock exchanges. Meanwhile, Chang, Faff \& Hwang (2010) pointed out a negative correlation between liquidity and stock returns, which is actually different from previous studies. Daily trading stock volume can be used to measure stock liquidity (Pástor \& Stambaugh, 2003). However, in the market, there exist stocks whose owners are restricted from freely transferring. Therefore, to measure the effectiveness of liquidity can use other ways. This article uses the liquid as the daily trading volume divided by the average volume of shares outstanding.

\section{Research Methodology}

In this section, first, the research model is established on the basis of the CAPM model and adds financial and liquidity factors as control variables for use in the research models. It aims to find out the effect of investor sentiment as measured by the Money Flow Index (MFI) indicator on stock returns. In the next section, the data sources used are specified. After that, the experimental steps are summarized in the research process.

\subsection{Money Flow Index Calculation}

This article uses the Money Flow Index (MFI) to measure investors' sentiment towards each stock on the Ho Chi Minh City Stock Exchange. The MFI was developed by two traders, Avrum Soudack and Gene Quong. It is one of the most commonly used momentum indicators in technical analysis. Changes in stock prices are calculated over a certain incremental time and range from 0 to 100. There are 4 steps to calculating the MFI for each stock:

Step 1: Calculate the average (typical) daily price of each stock.

During a trading day, a stock can match at many different prices. To determine a typical daily price per share, it is common practice to use a simple average of the highs, lows, and closures (Chen, Chong \& Duan, 2010).

$$
\text { Typical daily price }=\frac{\text { High }+ \text { Low }+ \text { Close }}{3}
$$

\section{Step 2: Calculate Money Flow}

It is important to understand what "money flow" means. The Money Flow for a day is calculated by multiplying the typical price by the volume traded for that day (Achelis, 2001). It refers to the volume of money in local currency, which is the total transaction value of a security.

$$
\text { Money flow }=\text { Typical price } * \text { Matching volume }
$$

On the bullish day, Money Flow was seen as representing buyer enthusiasm and on the day Money Flow decrease demonstrated the dominance of sellers. Excessive weighting in an up or down direction is understood to be extreme, likely to lead to a price reversal.

\section{Step 3: Calculate Money Flow ratio-MFR}

The money flow ratio is calculated by dividing total positive money flow by total negative money flow. If the current typical price is greater than the typical price of the previous day, then the money flow is positive. Conversely, if the current day's typical price is less than the typical price of the previous day, then the money flow is negative. For a trailing time window is usually 14 days (Achelis, 2001). Total positive Money Flow is the total number of days for 
which the typical price on the calculated date is higher than the typical price of the preceding day. Total negative Money Flow is the total number of days where the typical price on the calculated date is lower than the typical price of the preceding day. The typical rate constant date will be removed. Meanwhile, the money ratio is formed.

$$
\text { Money Flow Ratio }=\frac{\text { Positive Money Flow }}{\text { Negative Money Flow }}
$$

Step 4: Calculate the MFI

The MFI is an oscillator with a maximum value of 100 and a minimum of 0 . When the positive cash flow is relatively high, the oscillator approaches 100; in contrast, when the negative cash flow is relatively high, the oscillator approaches 0 . An MFI above 80 is generally considered overbought and an MFI below 20 is considered oversold. Use value of the money flow ratio to calculate the MFI based on the formula:

$$
\text { Money Flow Index }(M F I)=100-\frac{100}{1+\text { Money ratio }}
$$

\subsection{Research Models}

To test the effect of investor sentiment based on the MFI indicator on a stock's return, regression equation (6) whose MFI variable is used to compare with equation (5) - no has the variable MFI.

$$
\begin{gathered}
\mathrm{R}_{\mathrm{iF}}=\mathrm{R}_{\mathrm{i}, \mathrm{t}}-\mathrm{R}_{\mathrm{Fi}, \mathrm{t}}=\alpha_{0}+\beta_{1} \mathrm{x}\left(\mathrm{R}_{\mathrm{m}, \mathrm{it}}-\mathrm{R}_{\mathrm{Fi}, \mathrm{t}}\right)+\beta_{2} \mathrm{x} \frac{P_{i, t}}{\text { EPS }_{i, q-1}}+\beta_{3} \frac{P_{i, t}}{\text { Boovvalue }_{i, q-1}}+\beta_{4} \text { Liquidity }_{\mathrm{i}, \mathrm{t}}+\mathrm{e}_{\mathrm{i}, \mathrm{t}} \\
\text { Or } \mathrm{R}_{\mathrm{iF}}=\alpha_{0}+\beta_{1} \mathrm{R}_{\mathrm{mF}, \mathrm{t}}+\beta_{2} \mathrm{PE}+\beta_{3} \mathrm{~PB}+\beta_{4} \text { Liquidity }_{\mathrm{i}, \mathrm{t}}+\mathrm{e}_{\mathrm{i}, \mathrm{t}} \\
\mathrm{R}_{\mathrm{iF}}=\alpha_{0}+\beta_{1} \mathrm{R}_{\mathrm{mF}, \mathrm{it}}+\beta_{2} \mathrm{PE}+\beta_{3} \mathrm{~PB}+\beta_{4} \text { Liquidity }_{\mathrm{i}, \mathrm{t}}+\beta_{5} \mathrm{MFI}_{\mathrm{i}, \mathrm{t}}+\mathrm{e}_{\mathrm{i}, \mathrm{t}}
\end{gathered}
$$

The paper uses data groups related to stock trading, in financial statements and interest rates in the market. Trading data and financial data of listed companies (excluding banking) on the Ho Chi Minh City Stock Exchange used in the

\begin{tabular}{|c|c|c|c|}
\hline Data group & Variable name & Calculation method & Data source \\
\hline \multirow{5}{*}{$\begin{array}{l}\text { Transaction data } \\
\text { (daily) }\end{array}$} & $\mathrm{Pi}, \mathrm{t}$ & Closing price of share $\mathrm{i}$ at date $\mathrm{t}$ & http://hsx.vn \\
\hline & $\mathrm{Ri}, \mathrm{t}$ & $\begin{array}{l}\text { The rate of return of stock } i \text { at date } t \text {. It is calculated } \\
\text { in } \ln (\mathrm{Pt} / \mathrm{Pt}-1)\end{array}$ & \multirow{4}{*}{ http://fiinpro.com } \\
\hline & Rmt & $\begin{array}{l}\text { The market rate of return, which is calculated by the } \\
\text { VNIndex's rate at day t. }\end{array}$ & \\
\hline & Liquidityi,t & $\begin{array}{l}\text { The liquidity of stock } \mathrm{i} \text { at date } \mathrm{t} \text {, is calculated by the } \\
\text { daily matching volume divided by the average } \\
\text { volume of shares outstanding. }\end{array}$ & \\
\hline & MFIi,t & $\begin{array}{l}\text { Measuring investor sentiment towards stock } \mathrm{i} \text { at } \\
\text { date t, calculated using formula (4) }\end{array}$ & \\
\hline $\begin{array}{ll}\text { Risk-free rate } \\
\text { data (daily) }\end{array}$ & $\mathrm{RFi}, \mathrm{t}$ & $\begin{array}{l}\text { the nominal coupon rate of the 5-year government } \\
\text { bond is converted to a daily rate. }\end{array}$ & http://fiinpro.com \\
\hline \multirow{2}{*}{$\begin{array}{l}\text { Financial } \\
\text { (quarterly) }\end{array}$} & EPSt, q-1 & $\begin{array}{l}\text { Earnings per share of stock } i \text { in the quarter } \\
\text { preceding the transaction date }\end{array}$ & \multirow[t]{2}{*}{ http://fiinpro.com } \\
\hline & Bookvaluei,q-1 & $\begin{array}{l}\text { Book value per share of share } i \text { in the quarter } \\
\text { immediately preceding the transaction date. }\end{array}$ & \\
\hline
\end{tabular}
study must be continuous from the beginning of 2015 to the end of quarter 2, 2020. After the selection process, data from 138 listed companies were used in this study. Interest rate data is also collected for the period from the beginning of 2015 to the end of June 2020.

Table 1. Variable name, calculation method and data source

Source: Author collected and calculated 
MFI was used for the four models for estimating by equation (6). All MFI data from 2015 to June 2020 are used in model 2. MFI less than 20, MFI greater than 50, and MFI greater than 80 measure the three different levels of investor sentiment shown in the other three models.

\subsection{Research Process}

Based on the calculation steps outlined above, a research process is shown in Table 2.

Table 2. Research process

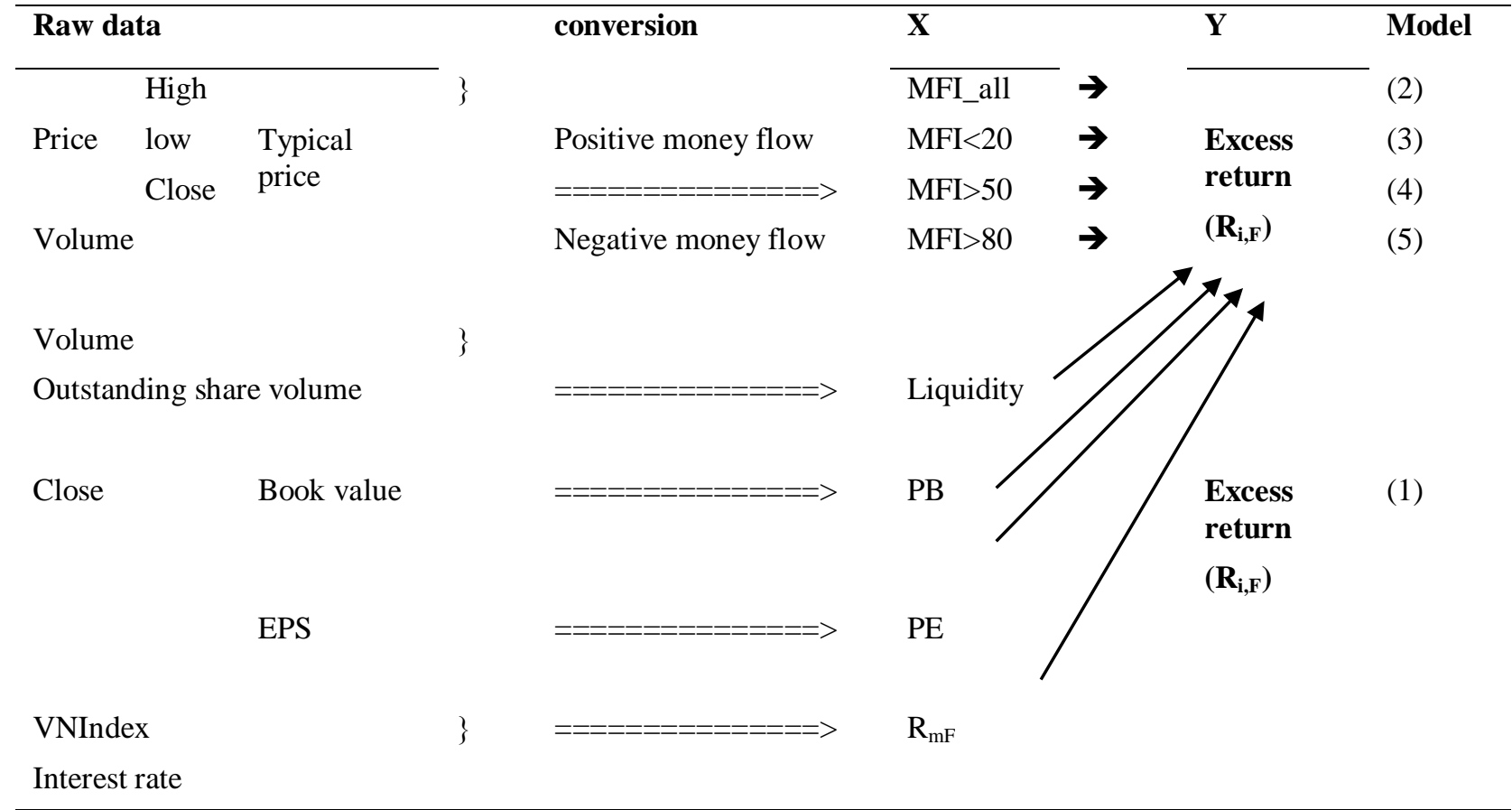

Source: Author construction

\section{Results and Discussion of Research Results}

Table 3. Descriptive statistics results

\begin{tabular}{lllll}
\hline Variable & $\mathbf{N}$ & mean & Median & Skewness \\
\hline rif & 184187 & -0.0004 & -0.0002 & -1.9738 \\
rmf & 184187 & 0.0001 & 0.0008 & -0.9300 \\
pe & 184187 & 16.35 & 8.89 & 29.9825 \\
pb & 184187 & 1.384 & 1.067 & 3.0596 \\
liquity & 184187 & 0.0038 & 0.0014 & 8.6916 \\
MFI & 184187 & 50.09 & 50.70 & -0.0751 \\
\hline
\end{tabular}

\begin{tabular}{lll}
\hline Year & VNIndex & P/E \\
\hline 2015 & 579.03 & 12.53 \\
2016 & 664.87 & 16.46 \\
2017 & 984.24 & 18.96 \\
2018 & 892.54 & 15.77 \\
2019 & 960.99 & 15.83 \\
F2020 & & $14-15 x$ \\
\hline
\end{tabular}

Source: Author's calculation and MBS (2020)

In the period from the beginning of 2015 to the end of the second quarter of 2020, the average daily rate of return of the VNIndex on Vietnam's stock market is always higher than the risk-free rate. The average PE of the stocks was $16 x$, respectively, equivalent to the average on the Vietnamese stock market during this period (Table 3). P/B's mean of 1.3 shows that investors do not accept to pay too high price when comparing the company's capitalization to their book value. On average, about $0.4 \%$ of outstanding shares are traded on a daily basis. It can be said that when considering the whole market, the Vietnamese stock market is developing normally, the average return on equity 
investment during this period is more attractive than the coupon rate of the government bonds. long-term - high safety. However, when weighting on the size of capitalization is ignored, the average daily stock return of 138 stocks listed on the Ho Chi Minh City Stock Exchange is negative. Therefore, there is attraction from the Vietnamese stock market during this period probably due to the lead of large enterprises leading the sectors and stocks of banking industry.

Since the mean is less than the median, Rif and Rmf are both left-tailed significantly (less than -0.5) from the normal distribution. This result shows that stocks with lower than average returns are more dispersed than stocks with higher than average returns.
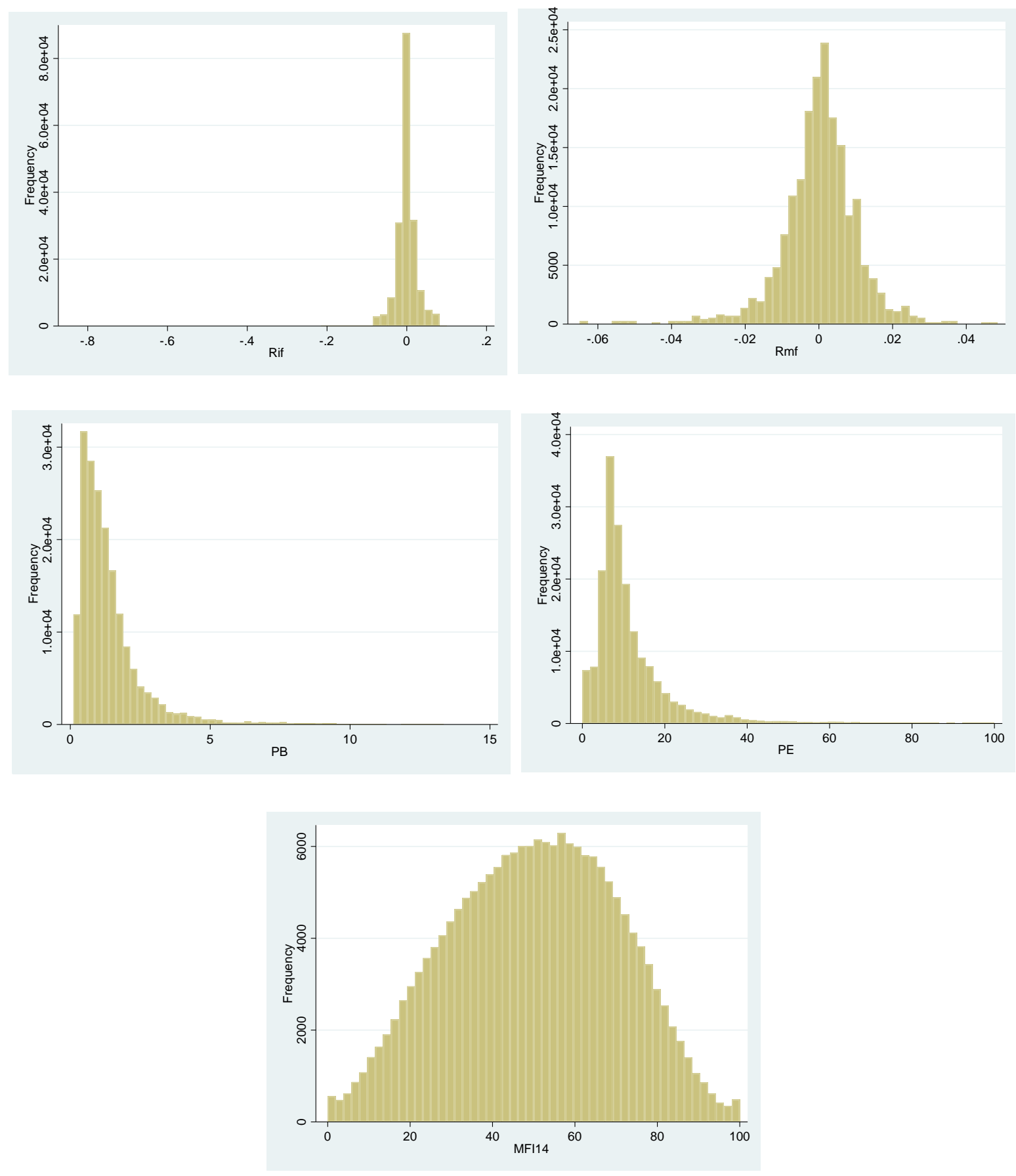

Figure 1 
Table 4. Correlation of pairs between variables

\begin{tabular}{llllllllll}
\hline & Rif & Rmf & PE & PB & Liquity & MFI & MFI $<20$ & MFI $>50$ & MFI $>80$ \\
\hline Rif & 1.000 & & & & & & & & \\
Rmf & 0.296 & 1.000 & & & & & & & \\
PE & 0.008 & 0.001 & 1.000 & & & & & & \\
PB & 0.021 & 0.014 & 0.001 & 1.000 & & & & & \\
Liquity & 0.059 & -0.010 & -0.009 & -0.106 & 1.000 & & & & \\
MFI & 0.146 & 0.051 & 0.012 & 0.067 & 0.131 & 1.000 & & & \\
MFI $<20$ & -0.072 & -0.032 & 0.003 & -0.048 & -0.056 & -0.533 & 1.000 & & \\
MFI $>50$ & 0.106 & 0.042 & 0.011 & 0.055 & 0.110 & 0.827 & -0.301 & 1.000 & \\
MFI $>80$ & 0.110 & 0.019 & 0.013 & 0.018 & 0.076 & 0.486 & -0.080 & 0.266 & 1.000 \\
\hline
\end{tabular}

Source: Author's calculation

The correlation analysis results show that the correlation between the MFI variable and the MFI variable less than 20, greater than 50, greater than 80 has absolute value greater than 0.5 . This is not surprising since these same variables are part of the MFI original data series. Therefore, to assess the impact between different MFI thresholds on stock returns, the four explanatory variables related to MFI are regressed in turn in the research models.

The remaining pairs of variables in the table have values less than 0.5 , so it is suitable for use in regression models with panel data.

Table 5. Results of the tests in the regression models

\begin{tabular}{llllll}
\hline Tests & & MFI & MFI $<20$ & MFI $>50$ & MFI >80 \\
$(1)$ & $(2)$ & $(3)$ & $(4)$ & $(5)$ \\
\hline Collin test (VIF) & $<2$ & $<2$ & $<2$ & $<2$ & $<2$ \\
Wooldridge test & $66.918(0.000)$ & $71.286(0.000)$ & $67.430(0.000)$ & $67.578(0.000)$ & 67.012 \\
Breusch and Pagan & 1.000 & 1.000 & 1.000 & 1.000 & $1.000(0.000)$ \\
test & $(0.000)$ & $(0.000)$ & $(0.000)$ & $(0.000)$ & \\
Wald test & $7422.10(0.000)$ & $7268.28(0.000)$ & $7355.20(0.000)$ & $7350.57(0.000)$ & 7272.57 \\
Hausman test & 395.08 & 2163.27 & 1463.54 & 1655.88 & 781.02 \\
F test & 3.34 & 2.15 & 3.41 & 2.57 & 2.36
\end{tabular}

Source: Author's calculation

Check for multi-collinearity phenomenon: The results show that VIF of all variables in the research models is less than 2 , so there is no multicollinearity phenomenon in these models.

Heteroscedasticity tests: The Breusch \& Pagan test and the Wald test both have P-value less than 0.05 . Therefore, the Random Effects Model (REM) and Fixed Effects Model (FEM) models are subject to variance varying across entities.

Test for autocorrelation: Wooldridge test shows that the models have autocorrelation phenomenon in panel data.

The P-value in the Hausman test are both greater than 0.05, showing no statistical difference between the REM model and the FEM model. This result shows that the random effects (REM) model is more suitable than the fixed effects model (FEM) because the error of eit is not correlated with the independent variables in the model. However, these models suffer from series autocorrelation and heterogeneous variance. Therefore, to overcome the 
heteroskedasticity and autocorrelation problems in the above models, this article uses the generalized least squares model (GLS). The advantage of this model is that it is possible to overcome all the phenomena of series autocorrelation and heterogeneous variance when regressing with panel data. After overcoming the defects in the model, the inference based on the results of the research models ensures efficiency and reliability.

Table 6. Results of the GLS regression

\begin{tabular}{|c|c|c|c|c|c|}
\hline Variable & $\begin{array}{l}\text { GLS } \\
\text { (1) }\end{array}$ & $\begin{array}{l}\text { GLS_MFIall } \\
\text { (2) }\end{array}$ & $\begin{array}{l}\text { GLS_MFI }<20 \\
\text { (3) }\end{array}$ & $\begin{array}{l}\text { GLS_MFI>50 } \\
\text { (4) }\end{array}$ & $\begin{array}{l}\text { GLS_MFI }>80 \\
\text { (5) }\end{array}$ \\
\hline Rmf & $0.6751 * * *$ & $0.6614 * * *$ & $0.6710 * * *$ & $0.6672 * * *$ & $0.6705 * * *$ \\
\hline $\mathrm{P} / \mathrm{E}$ & $0.0000 * * *$ & $0.0000 * * *$ & $0.0000 * * *$ & $0.0000 * * *$ & $0.0000 * * *$ \\
\hline $\mathrm{P} / \mathrm{B}$ & $0.0004 * * *$ & $0.0003 * * *$ & $0.0004 * * *$ & $0.0003 * * *$ & $0.0004 * * *$ \\
\hline Liquity & $0.2542 * * *$ & $0.1927 * * *$ & $0.2417 * * *$ & $0.2178 * * *$ & $0.2257 * * *$ \\
\hline MFI_all & & $0.0001 * * *$ & & & \\
\hline MFI $<20$ & & & $-0.0049 * * *$ & & \\
\hline $\mathrm{MFI}>50$ & & & & $0.0038 * * *$ & \\
\hline MFI $>80$ & & & & & $0.0089 * * *$ \\
\hline _cons & $-0.0020 * * *$ & $-0.0084 * * *$ & $-0.0015^{* * *}$ & $-0.0037 * * *$ & $-0.0024 * * *$ \\
\hline $\mathrm{N}$ & 184,187 & 184,187 & 184,187 & 184,187 & 184,187 \\
\hline $\operatorname{adjR} 2$ & 0.0923 & 0.1072 & 0.0957 & 0.0996 & 0.1023 \\
\hline
\end{tabular}

Source: Author's calculation

Figure 1 shows that the distribution of MFI is asymptotic to the normal distribution compared to other factors in the research models. Without distinguishing the different levels of the MFI, this indicator still shows its influence on the return of stocks (Table 6). In this case, the MFI positively affects the daily returns of stocks.

When investor sentiment is pessimistic, they will show it through action. This action caused the MFI to drop below 20 , the stock is being oversold. As a result, investor pessimism has a negative effect on the daily returns of listed stocks (Model 3). There is a view based on technical analysis that traders should turn to long positions when the MFI is below 20. However, the distribution density of MFI on the Vietnamese stock market peaked is relatively prison (Figure 1) so investors should still be cautious in this situation and consult other factors before make decision. One should wait for the MFI to move from the oversold territory above the 20 level.

Model 4 and Model 5 both show that investor sentiment is positive but to different degrees. When investor sentiment started to turn positive, MFI was greater than 50, the psychological factor affecting the profitability of securities also increased. The regression coefficient of the MFI variable in model 4 has increased significantly compared to it in model 2. Therefore, when other factors remain unchanged, a 1\% increase in MFI results in an average increase in stock returns from $0.01 \%$ (Model 2) to $0.38 \%$ (Model 4). The daily returns of stocks will be most affected by psychological factors when investors are in a state of excitement. In this situation the MFI is entering the overbought zone and the value is over 80 . The results from model 5 show that when other factors are unchanged, a $1 \%$ increase in MFI will increase stock returns on average from $0.89 \%$.

With a confidence level of $99 \%$, results from the 5 models in Table 5 show that the market risk premium (Rmf) is an important factor affecting the excess return of each stock (Rif). According to the theory in the capital asset pricing model (CAPM), the regression coefficient of variable Rmf is positive, showing that the movement of the general index on the stock market affects in the same direction with the excess profit of each stock. This is a reasonable result because in the long term, most stocks are always affected more or less from the general market.

Rmf has a Mean smaller than median, indicating that the distribution of Rmf is left-tailed (Table 2 and Figure 1). Furthermore, the Skewness of Rif less than -0.5 shows that the asymmetry of this distribution is significant. It shows the number of trade days in which the market return is above average with higher concentration than average, compared to the number of trade days where the market return is lower than average. 
All 5 regression models show that the PE coefficient has a significant impact on the excess return of stocks. The regression coefficient of PE is positive indicating coefficient PE positively affects the excess return of the security. This result supports the view that PE is the rate of income growth (Litzenberger \& Rao, 1971; Cragg \& Malkiel, 1982). Based on this point of view, analysts compare the PE ratio to earnings per share growth before recommending to buy any stock. However, the PE results in this study do not support Ball (1978) 's view when using the PE ratio as a measure of risk.

With the significance level of $1 \%$, the regression results from the research models show that PB ratio has a positive impact on stock returns. This finding is different from Mohanty (2002) when studying the Indian stock market, but supports the view that the PB ratio is an indicator of expected return on ROE (Kay, 1976; Brief \& Lawson, 1992). PB ratio of 138 stocks on the Vietnamese stock market in the research period has a mean 1.4 and has a right skew distribution form (Table $2 \&$ Graph 1). This shows that the majority of stocks are characterized by "value stocks" rather than "growth stocks" as classified by Capaul, Rowley \& Sharpe (1993).

Liquidity is one of the important criteria for investors to participate in the stock market. The regression results show that, with a confidence level of $99 \%$, liquidity has a significant impact on stock returns. Liquidity stocks are one of the criteria to increase their own daily returns. This result is very consistent with the fact that when the liquidity on the stock market is high, investors can easily convert from money to stocks and vice versa at low costs. This is an important criterion that can attract investors in the stock market. The Liquidity variable has a larger mean than the median (Table $2 \&$ Graph 1), which shows that the distribution is right tailed. In other words, stocks with higher than average liquidity are more dispersed than average lower liquidity stocks.

Comparing the results from the models with the MFI variable shows that when the MFI is in the oversold area (model 3) or the overbought zone (model 5), the roles of Rmf, PB, liquidity and sentiment Investor to stock returns are all higher than the rest of the models. In other words, at the threshold where psychology is strongly affected, the fundamentals (Rmf, PB) are paid more attention by investors and their behavior (liquidity) is more decisive than in the previous period.

\section{Conclusion}

This study has completed the testing of the effect of the psychological factor measured by the MFI indicator on the excess return of the stock on Vietnam's stock market. The different psychological levels are measured by the three MFI thresholds and the entire MFI data series to assess their impact in research models. By controlling the market risk premium in the CAPM model, the PE and PB ratios, the results confirm that the MFI and MFI sub-data affects excess return of companies listed on the Vietnam stock market. All MFI data and two sub-data, MFI> 50 (positive bias) and MFI> 80 (euphoria) both positively affect excess return stocks but at the impact levels are different. The impact level when investors are in a state of excitement (MFI 80$)$ is 2.3 times $(0.89 / 0.38)$ compared to when their psychology at MFI $>50$. The area of value near the lowest and highest point of the MFI is MFI $<20$ and MFI $>80$ are two important psychological areas. When MFI $<20$ represents an area where investors are concentrating on selling at a lower price than before - oversold area - causing negative impact on stock returns. When MFI> 80 represents an area where investors are concentrating on buying at a higher price than before - overbought zone - positively pushes to excess return of stock. In addition, factors such as PB, PE and stock liquidity at the value area near the starting and ending points also have a greater positive impact than the other regions. However, investors should note that when using $\mathrm{PE}$ and $\mathrm{PB}$ ratios as one of the decision-making criteria, it is necessary to have a comparison with the average $\mathrm{PE}$ of the industry and the market as a whole.

This study has a number of limitations that could open up research for further testing on the topic. First, the effect of MFI-based investor sentiment on the rate of return can be carried out across sectors to see different effects across sectors (including banking). Second, use a different measurement to quantify the effect of sentiment on stock returns. Combine these metrics into a composite index that reflects the sentiment that affects stock returns.

\section{References}

Achelis, S. B. (2001). Technical analysis from A to Z.

Amihud, Y., \& Mendelson, H. (1986). Asset pricing and the bid-ask spread. Journal of Financial Economics, 17(2), 223-249. https://doi.org/10.1016/0304-405X(86)90065-6

Ball, R. (1978). Anomalies in relationships between securities' yields and yield-surrogates. Journal of Financial Economics, 6(2-3), 103-126. https://doi.org/10.1016/0304-405X(78)90026-0

Capaul, C., Rowley, I., \& Sharpe, W. F. (1993). International value and growth stock returns. Financial Analysts 
Journal, 49(1), 27-36. https://doi.org/10.2469/faj.v49.n1.27

Chan, H. W., \& Faff, R. W. (2005). Asset pricing and the illiquidity premium. Financial Review, 40(4), 429-458. https://doi.org/10.1111/j.1540-6288.2005.00118.x

Chang, Y. Y., Faff, R., \& Hwang, C. Y. (2010). Liquidity and stock returns in Japan: New evidence. Pacific-Basin Finance Journal, 18(1), 90-115. https://doi.org/10.1016/j.pacfin.2009.09.001

Chen, H., Chong, T. T. L., \& Duan, X. (2010). A principal-component approach to measuring investor sentiment. Quantitative Finance, 10(4), 339-347. https://doi.org/10.1080/14697680903193389

Cragg, J. G., \& Malkiel, B. G. (2009). Expectations and the structure of share prices. University of Chicago Press.

Davis, J. L., Fama, E. F., \& French, K. R. (2000). Characteristics, covariances, and average returns: 1929 to 1997. The Journal of Finance, 55(1), 389-406. https://doi.org/10.1111/0022-1082.00209

Easley, D., \& O'hara, M. (1987). Price, trade size, and information in securities markets. Journal of Financial Economics, 19(1), 69-90. https://doi.org/10.1016/0304-405X(87)90029-8

Hirshleifer, D., \& Shumway, T. (2003). Good day sunshine: Stock returns and the weather. The Journal of Finance, 58(3), 1009-1032. https://doi.org/10.1111/1540-6261.00556

Krivelyova, A., \& Robotti, C. (2003). Playing the field: Geomagnetic storms and international stock markets (No. 2003-5a). Working Paper.

Lintner, J. (1965). Security prices, risk, and maximal gains from diversification. The Journal of Finance, 20(4), 587-615. https://doi.org/10.1111/j.1540-6261.1965.tb02930.x

Litzenberger, R. H., \& Rao, C. U. (1971). Estimates of the marginal rate of time preference and average risk aversion of investors in electric utility shares: 1960-66. The Bell Journal of Economics and Management Science, 265-277. https://doi.org/10.2307/3003167

Mohanty, P. (2002). Evidence of size effect on stock returns in India. Vikalpa, 27(3), 27-38. https://doi.org/10.1177/0256090920020304

Pástor, L., \& Stambaugh, R. F. (2003). Liquidity risk and expected stock returns. Journal of Political Economy, 111(3), 642-685. https://doi.org/10.1086/374184

Phuong, L. C. M. (2012). Nghiên cứu ảnh hưởng của chu kỳ mặt trăng đến lợi nhuận tại thị trường chứng khoán Việt Nam. Tạp ChÍ PhÁT Triển VÀ Hội Nhập, 2(2012), 75-78.

Phuong, L. C. M. (2017). The correlation of geomagnetic field to VN-Index return. Banking Technology Review, 1(1), 65-81.

Phuong, L. C. M. (2019). Hiệu ứng kỳ nghỉ, thời tiết, lịch âm đến tỷ suất sinh lợi của thị trường chứng khoán Việt Nam. Doctoral dissertation, Trường Đại học Kinh tế Tp. Hồ Chí Minh.

Phuong, L. C. M. (2020a). Investor sentiment by psychological line index and stock return. Accounting, 6(7), 1259-1264. https://doi.org/10.5267/j.ac.2020.8.026

Phuong, L. C. M. (2020b). Investor sentiment by relative strength index and stock return: Empirical evidence on Vietnam's stock market. Accounting, 7(2), 451-456. https://doi.org/10.5267/j.ac.2020.11.006

Sharpe, W. F. (1964). Capital asset prices: A theory of market equilibrium under conditions of risk. The Journal of Finance, 19(3), 425-442. https://doi.org/10.1111/j.1540-6261.1964.tb02865.x

Stattman, D. (1980). Book values and stock returns. The Chicago MBA: A Journal of Selected Papers, 4(1), 25-45.

Yuan, K., Zheng, L., \& Zhu, Q. (2006). Are investors moonstruck? Lunar phases and stock returns. Journal of Empirical Finance, 13(1), 1-23. https://doi.org/10.1016/j.jempfin.2005.06.001

\section{Copyrights}

Copyright for this article is retained by the author(s), with first publication rights granted to the journal.

This is an open-access article distributed under the terms and conditions of the Creative Commons Attribution license (http://creativecommons.org/licenses/by/4.0/). 